\title{
Production of parsley in hydroponic conditions under isosmotic brackish nutrient solutions
}

\section{Produção da salsa em condições hidropônicas sob soluções nutritivas salobras isosmóticas}

\author{
Juliana Bezerra Martins ${ }^{1 *}$ (D) José Amilton Santos Júnior² ${ }^{(D)}$, \\ Fernando José da Silva Júnior ${ }^{2}$ (D) Gerônimo Ferreira da Silva² (iD), Salomão de Sousa Medeiros ${ }^{3}$ iD
}

\author{
'Universidade Federal Rural de Pernambuco/UFRPE, Dois Irmãos, Recife, PE, Brasil \\ ${ }^{2}$ Dom Manuel de Medeiros, Dois Irmãos, Recife, PE, Brasil \\ ${ }^{3}$ Ministério da Ciência, Tecnologia, Inovações e Comunicações, Instituto Nacional do Semiárido, Campina Grande, PB, Brasil \\ *Corresponding author: julianaabmartins@gmail.com \\ Received in October 6, 2018 and approved in January 25, 2019
}

\begin{abstract}
Brackish waters may vary in their chemical compositions, interfering with different plant responses to stress; therefore, the present study aimed to evaluate the production components of parsley plants subjected to levels of electrical conductivity in nutrient solutions with an initial ECns of $1.58 \mathrm{dS} \mathrm{m}^{-1}$, which was solubilized in water with the following water electrical conductivity configurations (ECW): 0.12 (control), $1.12,2.12,3.12,4.12$ and $5.12 \mathrm{dS} \mathrm{m}^{-1}$, resulting in six isosmotic levels $\left(E C_{\mathrm{ns}}=1.7,2.7,3.7,4.7,5.7\right.$ and $\left.6.7 \mathrm{dS} \mathrm{m}^{-1}\right)$ in an interaction with four types of salt: $\mathrm{NaCl}, \mathrm{CaCl}_{2}, \mathrm{MgCl}_{2}$ and $\mathrm{KCl}$. The experimental design was completely randomized in a factorial scheme with five replicates. Two strategies were used to restore the volume consumed by the parsley plants, and the replacement was made with municipal-supply water $\left(E C a=0.12 \mathrm{dS} \mathrm{m}^{-1}\right)$ in the first strategy and with the respective brackish waters in the second strategy. The total fresh and dry weights of the shoots and roots were evaluated as well as the total dry mass percentage of the shoots and roots. The responses of the plants to the different cationic natures was more evident at the highest levels of electrical conductivity tested, and the use of municipal-supply water to replace the evapotranspired depth mitigated the deleterious effects of salinity. In addition, greater reductions were observed in the fresh and dry mass when the replacement of the volume consumed was with the brackish waters.
\end{abstract}

Index terms: Petroselinum crispum; salinity; cationic nature; hydroponics.

\section{RESUMO}

As águas salobras podem apresentar variação na sua composição química, interferindo em diferentes respostas das plantas frente ao estresse, então, o presente trabalho objetivou-se em avaliar os componentes de produção da salsa submetida a níveis de condutividade

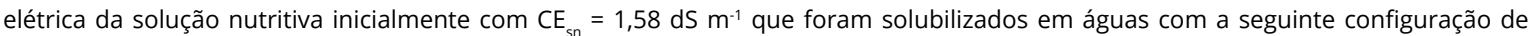
condutividade elétrica da água ( $\left.\mathrm{CE}_{\mathrm{a}}\right): 0,12$ (controle); 1,$12 ; 2,12 ; 3,12 ; 4,12$ e 5,12 dS m-1 resultando em seis níveis isosmóticos $\left(\mathrm{CE}_{\mathrm{sn}}=1,7 ;\right.$ 2,$7 ; 3,7 ; 4,7 ; 5,7$ e $6,7 \mathrm{dS} \mathrm{m}^{-1}$ ) em interação com quatro tipos de sais $\mathrm{NaCl}, \mathrm{CaCl}_{2}, \mathrm{MgCl}_{2}$ e $\mathrm{KCl}$. O delineamento experimental foi inteiramente casualizado, em esquema fatorial com cinco repetições. Foram utilizadas duas estratégias para reposição do volume consumido pelas plantas de salsa, no primeiro experimento, a reposição foi com água de abastecimento municipal $\left(\mathrm{CE}_{\mathrm{a}}=0,12 \mathrm{dS} \mathrm{m}^{-1}\right)$, e no segundo com as respectivas águas salobras Foram avaliadas a massa fresca e seca total, da parte aérea e da raiz, bem como o percentual de massa seca total da parte aérea e da raiz. A resposta das plantas às diferentes naturezas catiônicas foi mais evidente nos maiores níveis de condutividade elétricas testados e o uso de água de abastecimento na reposição da lâmina evapotranspirada mitigou os efeitos deletérios da salinidade, além disso foram verificadas maiores reduções nas massas frescas e secas quando a reposição do volume consumido foi com as águas salobras.

Termos para indexação: Petroselinum crispum; salinidade; natureza catiônica; hidroponia.

\section{INTRODUCTION}

Parsley is an herb in the Apiaceae family, and its leaves are widely used in cooking, either cooked or raw. It is also considered an important source of vitamins; in addition, it has compounds such as flavonoids, carotenoids and ascorbic acid (Maodaa et al., 2016), which are bioactive compounds with antioxidant capacity that have been associated with the protection of human health against chronic degenerative diseases (Lako et al., 2007; Reis et al., 2015). 
Studies on parsley have mainly focused on its use as a source of food and its effects on human health (Snoussi et al., 2016; Nirumand et al., 2018). However, research related to its production is still scarce, especially in the Brazilian semiarid region.

In this region, underground waters, which are sometimes the only water available for agriculture, are characterized by a high salt content (Montenegro et al., 2013), which is a limiting factor for irrigated agriculture, since salinity interferes with the physiological and biochemical functions of plants, causing a reduction in the production and yield of crops (Torres et al., 2014; Munns; Gilliham, 2015).

Specifically, regarding the salinity of the waters in the Brazilian semiarid region, Holanda et al. (2016) commented that most of the sources contain salts of different natures $\left(\mathrm{Ca}^{2+}, \mathrm{Mg}^{2+}, \mathrm{K}^{+}, \mathrm{Na}^{+}, \mathrm{CO}_{3}{ }^{-}, \mathrm{HCO}_{3}{ }^{-}\right.$and $\left.\mathrm{Cl}^{-}\right)$ in different quantities, which, depending on the agricultural use, may result in precipitation reactions that limit the absorption of some nutrients by plants, antagonistic interactions among nutrients during absorption by roots and alterations of the solution $\mathrm{pH}$ (Santos et al., 2017).

In this context, the use of brackish waters in agricultural production requires the utilization of adequate cultivation techniques and forms of management that are important, such as hydroponic cultivation (Santos Júnior et al., 2015), and strategies of brackish water use to replace the water metabolized by plants (Bione et al., 2014).

Compared to cultivation in soil, in hydroponic cultivation, the energetic reordering of water potential due to the absence of a soil matrix favors the use of brackish waters in the production process, leading to more expressive results for the same level of salinity (Santos Júnior et al., 2015).

Even in the context of hydroponic cultivation, strategies using brackish water to prepare and replace the evapotranspired nutrient solution with waters of different levels of electrical conductivity (Freitas et al., 2014; Campos Júnior et al., 2018) can further mitigate the effects of salts on plants (Guedes et al., 2015), in addition to rationalizing the use of waters with different salt contents, increasing the water supply (Santos Júnior et al., 2016).

In short, the production of leafy vegetables in hydroponic systems using brackish waters to prepare and manage nutrient solutions has been studied and recommended by different authors (Rebouças et al., 2013; Souza Neta et al., 2013; Bione et al., 2014; Santos Júnior et al., 2015; Silva et al., 2015), who indicated a good yield, early harvest and the reduced use of pesticides among other advantages. In addition, under hydroponic cultivation conditions, physical changes occur in the energy levels. Due to the absence of soil, the matrix potential tends to be zero, making the osmotic influence decisive on the total potential (Santos Júnior et al., 2015).

Given the above, the present study aimed to evaluate the production components of Petroselinum crispum plants subjected to isosmotic levels of electrical conductivity of brackish nutrient solutions prepared in waters salinized by $\mathrm{NaCl}, \mathrm{CaCl}_{2}, \mathrm{MgCl}_{2}$ and $\mathrm{KCl}$.

\section{MATERIAL AND METHODS}

\section{Study location}

Two experiments were conducted between October 2017 and February 2018 in a protected environment at the Federal Rural University of Pernambuco (UFRPE), Recife - PE, Brazil ( $8^{\circ} 01^{\prime} 07^{\prime}$ ' $\mathrm{S}, 34^{\circ} 56^{\prime} 53^{\prime \prime} \mathrm{W}$ and mean altitude of $6.5 \mathrm{~m}$ ) with the following dimensions: $6.0 \mathrm{~m}$ wide, 18.0 $\mathrm{m}$ long, $4.0 \mathrm{~m}$ on the right and $5.5 \mathrm{~m}$ on the highest part of the structure. The roof covering consisted of a transparent, low density, polyethylene blanket that was treated against the effects of ultraviolet rays.

During the experiments, inside the protected environment, the mean maximum and minimum temperatures were $37.5^{\circ} \mathrm{C}$ and $31{ }^{\circ} \mathrm{C}$, respectively, with mean maximum and minimum relative air humidity values of $62.5 \%$ and $45.3 \%$, respectively. Both measurements were taken using a digital thermometer. There was no negative interference of the climate on plant development.

\section{Treatments, design and experimental structure}

A completely randomized experimental design, analyzed in a $6 \times 4$ factorial scheme with five replicates, was adopted to test six levels of electrical conductivity of the nutrient solutions $\left(\mathrm{EC}_{\mathrm{ns}}\right)$ : 1.7 (control, without salt), 2.7, 3.7, 4.7, 5.7 and $6.7 \mathrm{dS} \mathrm{m}^{-1}$; the solutions were obtained by adding $\mathrm{NaCl}, \mathrm{CaCl}_{2}, \mathrm{MgCl}_{2}$ and $\mathrm{KCl}$, the four cationic natures of salt.

The control treatment $\left(\mathrm{ECns}=1.7 \mathrm{dS} \mathrm{m}^{-1}\right)$ was obtained by adding the fertilizer salts to municipal-supply water $\left(E C w=0.12 \mathrm{dS} \mathrm{m}^{-1}\right)$. For the ECns levels of 2.7, 3.7, 4.7, 5.7 and $6.7 \mathrm{dS} \mathrm{m}^{-1}$, the waters were initially prepared by diluting increasing quantities of $\mathrm{NaCl}, \mathrm{CaCl}_{2}, \mathrm{MgCl}_{2}$ and $\mathrm{KCl}$ in municipal-supply water $\left(\mathrm{EC}=0.12 \mathrm{dS} \mathrm{m}^{-1}\right)$, establishing the following levels: 1.12, 2.12, 3.12, 4.12 and $5.12 \mathrm{dS} \mathrm{m}^{-1}$. These waters were stored in $90 \mathrm{~L}$ tanks, and then the fertilizers were solubilized in the quantities of fertilizers used recommended by Furlani et al. (1999) for leafy vegetables. The experiments differed only by the 
water used to replenish the individual tanks of nutrient solution, whose volume was naturally reduced by the consumption of plants, i.e., municipal-supply water (ECw $=0.12 \mathrm{dS} \mathrm{m}^{-1}$ ) was used in the first cycle, and the respective brackish waters used to prepare the nutrient solution were used in the second cycle.

The hydroponic system adopted consisted of 6-m-long and 100-mm-diameter gutters made of PVC pipes with 60 -mm-diameter holes every $0.14 \mathrm{~m}$. On both ends, elbows were installed, and one elbow was connected to a faucet to guarantee the formation of a nutrient solution film inside the pipe, which was level and $0.4 \mathrm{~m}$ high (Santos Júnior et al., 2016); in these tubes, drilled circular 60 -mm-diameter "cells" were spaced evenly every $7 \mathrm{~cm}$. The cells corresponded to the experimental plots, and each tube corresponded to a treatment (Figure 1).
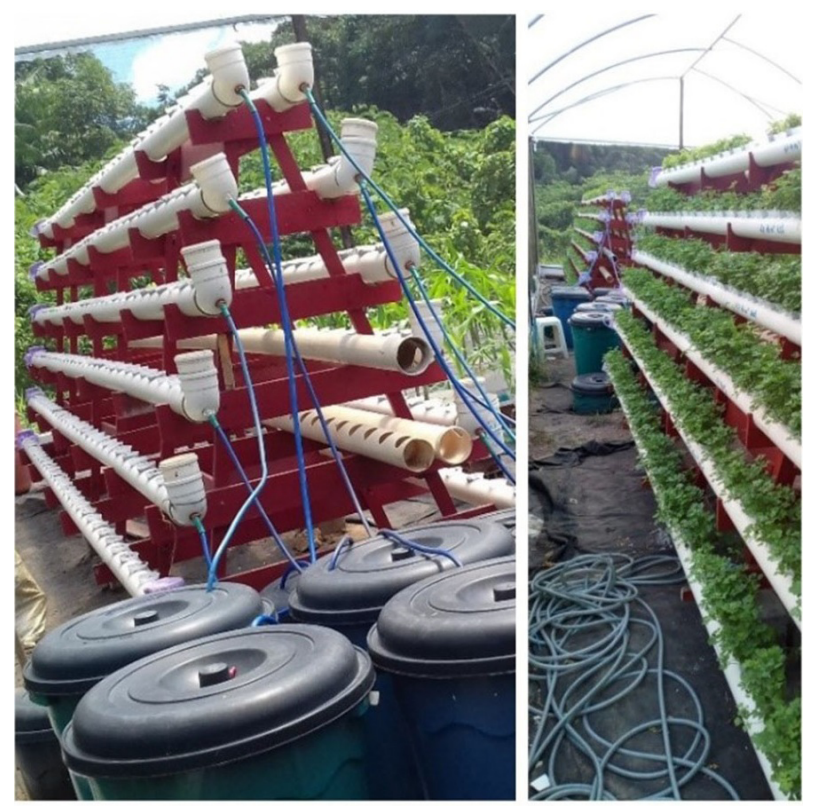

Figure 1: Low-cost hydroponic system.

\section{Cultivation conduction and nutrient solution management}

Parsley (Petroselinum crispum), cv. Graúda portuguesa, was the reference crop. The seeds were sown in October 2017 (first experiment) and December 2018 (second experiment) in 180-mL disposable plastic cups that were perforated at the bottom and lower third of the sides; the cups were filled with coconut fiber for the sowing of 45 seeds without thinning. In the first ten days after sowing (DAS), the substrate moisture was maintained with two daily applications of $20 \mathrm{~mL}$ of water with a low salt concentration (EC $\left.=0.12 \mathrm{dS} \mathrm{m}^{-1}\right)$.

For the management of the nutrient solution, a closed system was adopted, i.e., the nutrient solution was prepared only once at the beginning of the experiment; twice a day (7:00 and 15:00 h), 20 L of nutrient solution was applied in the pipes, and the surplus returned to the tank through hoses. The level in this tank was replenished every seven days using municipal-supply water or brackish water in the first and second cycles, respectively. Variations in the $\mathrm{EC}_{\mathrm{ns}}$ and the nutrient solution $\mathrm{pH}\left(\mathrm{pH}_{\mathrm{ns}}\right)$ were monitored every two days in the $90 \mathrm{~L}$ tanks, and regarding the phytosanitary aspects of the crop, there was no incidence of pests or diseases during the cultivation cycles.

At the end of each cycle (50 DAS), the following variables were evaluated: the total fresh matter (TFM), the shoot fresh matter (SFM) and the root fresh matter (RFM), which were collected and weighed on a $0.01 \mathrm{~g}$ precision scale; the plants were cut close to the substrate, and the shoot and root were weighed separately, after which a sum of the two parts was taken to obtain the total matter. Posteriorly, the materials were separately identified in paper bags that were properly identified and dried in a forced-air oven at $60{ }^{\circ} \mathrm{C}$ until a constant weight was obtained for later obtaining the total dry matter (TDM), the shoot dry matter (SDM) and the root dry matter (RDM). These results were used to calculate the \%SDM, \%RDM and $\%$ TDM by relating the dry matter to the fresh matter using the following equation: $\% \mathrm{DM}=($ dry matter $/$ fresh matter) x 100 .

The results were subjected to analysis of variance by an $\mathrm{F}$ test. The levels of the nutrient solution electrical conductivity (quantitative factors) were compared by regression analysis, whereas the cationic natures of the water (qualitative factors) were compared by a test of means (Tukey). All the analyses were conducted at the 0.05 probability level using a statistical program (Ferreira, 2011).

\section{RESULTS AND DISCUSSION}

A trend of reduction was observed in the $\mathrm{EC}_{\mathrm{ns}}$ when municipal-supply water was used in the replacement for all the levels studied, especially 5.7 $\mathrm{dS} \mathrm{m} \mathrm{m}^{-1}$ and $6.7 \mathrm{dS} \mathrm{m}^{-1}$, both in the nutrient solution prepared with $\mathrm{KCl}$, compared with the initial values (Figure 2A). 
Under replacement with brackish water, there was an increasing trend, especially from 35 DAS at levels higher than $3.7 \mathrm{dS} \mathrm{m}^{-1}$, particularly in the solutions prepared with $\mathrm{KCl}$ and $\mathrm{MgCl}_{2}$, both at a level of $6.7 \mathrm{dS}$ $\mathrm{m}^{-1}$ (Figure 2B), compared with the initial $\mathrm{EC}_{\mathrm{ns}}$. In general, the reduction observed in the $\mathrm{EC}_{\mathrm{ns}}$ under replacement with municipal-supply water can be attributed to the dilution of salts caused by the addition of water with few minerals $\left(0.12 \mathrm{dS} \mathrm{m}^{-1}\right)$. Conversely, the increase observed under replacement with brackish water was due to the supply of salts upon replacement, which was also observed by Campos Júnior et al. (2018), who worked with rockets and used brackish water in the replacement of the evapotranspirated volume.

Regarding the $\mathrm{pH}_{\mathrm{ns}}$, under replacement with municipal-supply water, compared with the initial values in the treatment based on $\mathrm{KCl}$, there were reductions up to $15 \%$, at an $\mathrm{EC}$ of $1.7 \mathrm{dS} \mathrm{m}^{-1}$, reaching a value of 5.5 at the end of the cycle (50 DAS) (Figure 3A).

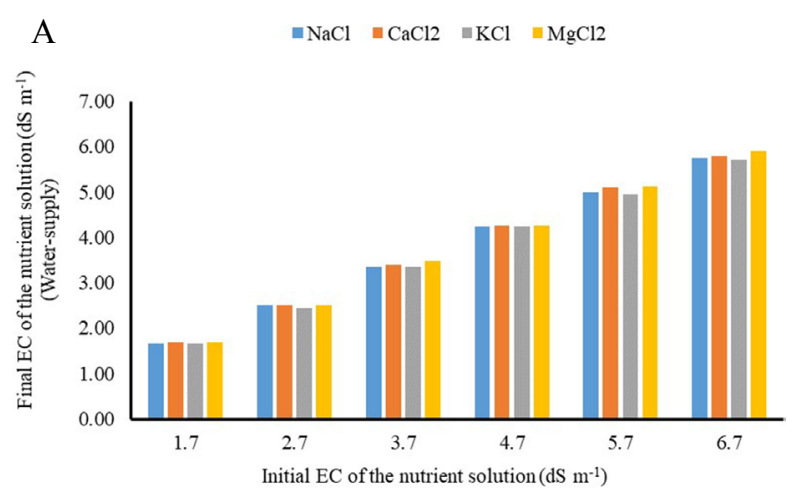

Under replacement with brackish water, the highest variations in the $\mathrm{pH}_{\mathrm{ns}}$ occurred in the treatment of $3.7 \mathrm{dS} \mathrm{m}^{-1}$ in the solution prepared with $\mathrm{KCl}$, showing a maximum reduction of $11.47 \%$ (Figure 3B). For the $\mathrm{pH}_{\mathrm{ns}}$, the variations did not exceed the range from 5.5 to 6.5 cited by Silva et al. (2018), which may be attributed to the cationic nature of the salts (except $\mathrm{MgCl}_{2}$ ), originating from the reactions of strong acids with strong bases, which did not cause abrupt changes in the $\mathrm{pH}$, even with the increase in $\mathrm{EC}_{\mathrm{ns}}$.

Individually, the treatments caused significant differences $(p<0.05)$ in the total fresh matter (TFM), shoot fresh matter (SFM) and root fresh matter (RFM) under replacement with municipal-supply water. The interaction between the treatments significantly $(\mathrm{p}<0.05)$ influenced the TFM and SFM under replacement with municipal-supply water (Table 1).

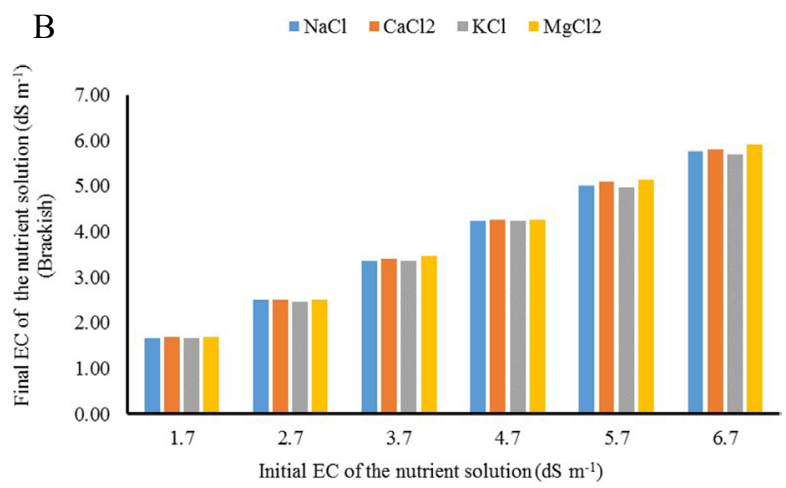

Figure 2: Electrical conductivity of the nutrient solution under replenishment with municipal-supply water (A) and brackish water (B) for the parsley plants (cv. Graúda portuguesa) cultivated with low-cost hydroponics.

$\varpi \mathrm{NaCl}=\mathrm{CaCl} 2 \quad \square \mathrm{KCl} \quad \square \mathrm{MgCl} 2$

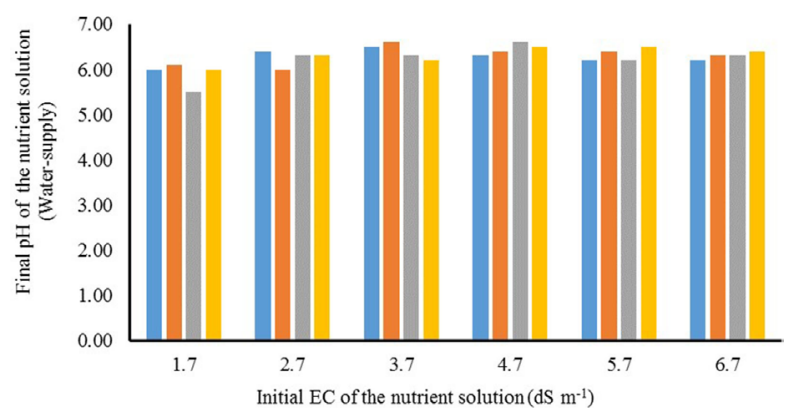

$\because \mathrm{NaCl} \backsim \mathrm{CaCl} 2=\mathrm{KCl}=\mathrm{MgCl} 2$

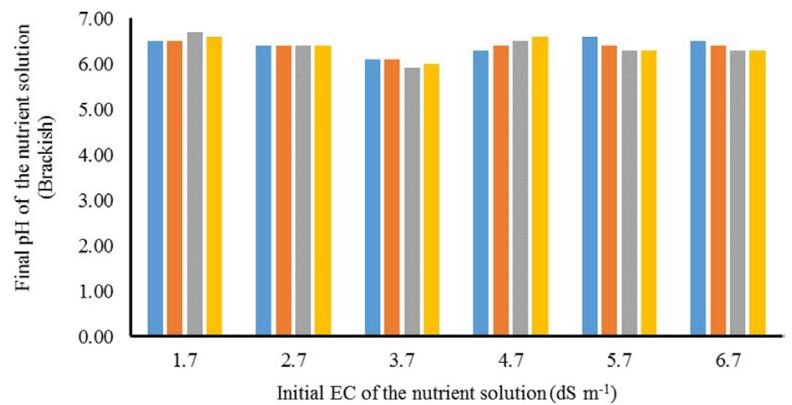

Figure 3: The $\mathrm{pH}$ of the nutrient solution under replenishment with municipal-supply water $(\mathrm{A})$ and brackish water (B) for parsley plants (cv. Graúda portuguesa) cultivated with low-cost hydroponics. 
Table 1: The total fresh matter (TFM), shoot fresh matter (SFM) and root fresh matter (RFM) results of parsley plants, cv. 'Graúda Portuguesa', exposed to isosmotic brackish nutrient solutions prepared in waters with different cationic natures and responses with municipal-supply water.

\begin{tabular}{|c|c|c|c|c|c|c|c|}
\hline \multicolumn{8}{|c|}{ EC of the nutrient solution $\left(\mathrm{dS} \mathrm{m}^{-1}\right)$} \\
\hline & 1.7 & 2.7 & 3.7 & 4.7 & 5.7 & 6.7 & \\
\hline \multicolumn{8}{|c|}{${ }^{1}$ TFM (g) - Municipal-supply ( $\left.E C_{n s}: p<0.05, C N: p<0.05 ; E_{n s} v s C N: p<0.05, C V=4.63 \%\right)$} \\
\hline $\mathrm{NaCl}$ & $69.56 a$ & $58.37 a$ & 48.69a & $38.72 a$ & $35.41 \mathrm{a}$ & $29.84 a$ & $\begin{array}{c}y=-7.9271^{* *} x+80.059 \\
R^{2}=0.9662\end{array}$ \\
\hline $\mathrm{CaCl}_{2}$ & $65.18 \mathrm{a}$ & $52.43 b$ & $44.51 b c$ & $34.97 b c$ & $25.08 b$ & $20.41 b$ & $\begin{array}{c}y=-9.0126^{* *} x+78.283 \\
R^{2}=0.9875\end{array}$ \\
\hline $\mathrm{MgCl}_{2}$ & $62.51 \mathrm{a}$ & $46.92 c$ & $42.83 \mathrm{c}$ & $34.55 c$ & $26.15 b$ & 21.93b & $\begin{aligned} & y=-7.814^{* *} x+71.967 \\
& R^{2}=0.9659\end{aligned}$ \\
\hline $\mathrm{KCl}$ & $69.20 a$ & $54.41 \mathrm{~b}$ & $46.71 \mathrm{ab}$ & 38.05ab & $35.00 a$ & $29.89 a$ & $\begin{array}{c}y=-7.5269^{* *} x+77.156 \\
R^{2}=0.9425\end{array}$ \\
\hline \multicolumn{8}{|c|}{${ }^{1}$ SFM (g) - Municipal-supply (EC ${ }_{n s}$ : $\left.p<0.05, C N: p<0.05, E_{n s} v s C N: p<0.05, C V=4.95 \%\right)$} \\
\hline $\mathrm{NaCl}$ & $49.58 a$ & $42.92 \mathrm{a}$ & $36.62 \mathrm{a}$ & $28.83 a$ & $26.67 a$ & $23.01 a$ & $\begin{array}{c}y=-5.4111^{* *} x+57.332 \\
R^{2}=0.9701\end{array}$ \\
\hline $\mathrm{CaCl}_{2}$ & $47.01 \mathrm{a}$ & $38.86 b$ & 33.08b & $27.25 a$ & $18.56 b$ & $16.33 b$ & $\begin{array}{c}y=-6.2894^{* *} x+56.597 \\
R^{2}=0.9855\end{array}$ \\
\hline $\mathrm{MgCl}_{2}$ & $45.73 a$ & $33.94 \mathrm{c}$ & $32.87 \mathrm{~b}$ & $27.05 a$ & $20.61 b$ & $18.15 b$ & $\begin{array}{c}y=-5.2489^{* *} x+51.77 \\
R^{2}=0.949\end{array}$ \\
\hline $\mathrm{KCl}$ & $49.95 a$ & $40.61 \mathrm{ab}$ & $35.21 a$ & $28.45 a$ & $26.98 a$ & $22.78 a$ & $\begin{array}{c}y=-5.2429^{* *} x+56.017 \\
R^{2}=0.9515\end{array}$ \\
\hline \multicolumn{8}{|c|}{$\begin{array}{c}\text { RFM (g) - Municipal-supply } \\
\left(E C_{n s}: p<0.05, C N: p<0.05, E C_{n s} v s C N: p>0.05, C V=10.88 \%\right)\end{array}$} \\
\hline & & $\begin{array}{c}\mathrm{NaCl} \\
11.99 \mathrm{a}\end{array}$ & $\begin{array}{c}\mathrm{CaCl}_{2} \\
10.25 \mathrm{c}\end{array}$ & $\begin{array}{l}\mathrm{MgCl}_{2} \\
9.42 \mathrm{~d}\end{array}$ & $\begin{array}{c}\mathrm{KCl} \\
11.04 \mathrm{~b}\end{array}$ & & $\begin{array}{c}y=0.9543^{* *} x+86.048 \\
R^{2}=0.9727\end{array}$ \\
\hline
\end{tabular}

${ }^{1}$ Different letters in the column indicate significant differences between the cationic natures at the 0.05 probability level by the test of means (Tukey). $\mathrm{EC}_{\mathrm{ns}}$ : electrical conductivity of the nutrient solution; CN: cationic nature; CV : coefficient of variation.

In the interaction between the treatments under replacement with municipal-supply water, there was a linear reduction in the TFM as a function of the $\mathrm{EC}_{\mathrm{ns}}$ levels, but as the salinity increased from $2.7 \mathrm{dS} \mathrm{m}^{-1}$, the TFM was $24.40 \%$ higher than that of the plants under $\mathrm{NaCl}$ and $\mathrm{MgCl}_{2}$; the analysis demonstrates the difference in the effect of different salts on plants (Table 1).

Reductions in the SFM under replacement with municipal-supply water were observed; in addition, compared with $\mathrm{CaCl}_{2}$ and $\mathrm{MgCl}_{2}$, a difference $(\mathrm{p}<0.05)$ in the effect of the salts was found from $2.7 \mathrm{dS} \mathrm{m}^{-1}$, especially in the SFM of the plants under $\mathrm{NaCl}$ and $\mathrm{KCl}$ (Table 1).

In the same way, there were reductions in the RFM under municipal-supply water, which, in spite of not having been significantly influenced in the interaction between the treatments, showed more expressive results when cultivated in solutions based on $\mathrm{NaCl}$ and $\mathrm{KCl}$ (Table 1).
There were greater losses of TFM, SFM and RFM in the plants exposed to salinity induced by divalent cations under replacement with municipal-supply water, which may be related to the higher speed of absorption of monovalent cations compared to divalent cations (Abrahão; Bôas; Bull, 2014).

Individually, the treatments caused significant differences $(p<0.05)$ in the total fresh matter (TFM), shoot fresh matter (SFM) and root fresh matter (RFM) under replacement with brackish water. The interaction between the treatments significantly $(\mathrm{p}<0.05)$ influenced the RFM under replacement with brackish water (Table 2).

Under replacement with brackish water for the TFM and SFM, differences $(\mathrm{p}<0.05)$ between the cationic nature were observed with $\mathrm{NaCl}$, in which the plants cultivated under $\mathrm{NaCl}$ presented more expressive results. In addition, there were linear reductions with the increase in salinity regardless of the cationic nature used in the nutrient solution (Table 2). 
Table 2: The total fresh matter (TFM), shoot fresh matter (SFM) and root fresh matter (RFM) results of parsley plants, cv. 'Graúda Portuguesa', exposed to isosmotic brackish nutrient solutions prepared in waters with different cationic natures and responses with brackish water.

\begin{tabular}{|c|c|c|c|c|c|c|c|}
\hline \multicolumn{8}{|c|}{ EC of the nutrient solution $\left(\mathrm{dS}^{-1}\right)$} \\
\hline & 1.7 & 2.7 & 3.7 & 4.7 & 5.7 & 6.7 & \\
\hline \multicolumn{7}{|c|}{$\begin{array}{l}\text { TFM (g) - Brackish } \\
\left(E C_{n s}: p<0.05, C N: p<0.05, E C_{n s} v s C N: p>0.05, C V=4.46 \%\right)\end{array}$} & \multirow{3}{*}{$\begin{array}{c}y=-5.0017^{* *} x+58.511 \\
R^{2}=0.9932\end{array}$} \\
\hline & & $\mathrm{NaCl}$ & $\mathrm{CaCl}_{2}$ & $\mathrm{MgCl}_{2}$ & $\mathrm{KCl}$ & & \\
\hline & & $38.34 a$ & $36.87 b$ & $37.44 a b$ & $37.35 \mathrm{ab}$ & & \\
\hline \multicolumn{7}{|c|}{$\begin{array}{l}\text { SFM (g) - Brackish } \\
\left(E C_{n s}: p<0.05, C N: p<0.05, E C_{n s} v s C N: p>0.05, C V=5.54 \%\right)\end{array}$} & \multirow{3}{*}{$\begin{array}{c}y=-4.2546^{* *} x+48.918 \\
R^{2}=0.9937\end{array}$} \\
\hline & & $\mathrm{NaCl}$ & $\mathrm{CaCl}_{2}$ & $\mathrm{MgCl}_{2}$ & $\mathrm{KCl}$ & & \\
\hline & & $31.88 a$ & $30.47 \mathrm{~b}$ & $31.26 a b$ & $30.58 b$ & & \\
\hline \multicolumn{8}{|c|}{${ }^{1}$ RFM (g) - Brackish (EC $\left.{ }_{n s}: p<0.05, C N: p<0.05, E C_{n s} v s C N: p<0.05, C V=4.71 \%\right)$} \\
\hline $\mathrm{NaCl}$ & $8.24 a$ & $7.37 a$ & $6.75 a$ & $6.06 a$ & $5.33 a b$ & $5.00 a$ & $\begin{array}{c}y=-0.6574^{* *} x+9.2195 \\
R^{2}=0.9888\end{array}$ \\
\hline $\mathrm{CaCl}_{2}$ & $8.46 a$ & $7.42 \mathrm{a}$ & $6.39 a$ & $5.63 a$ & $5.35 a$ & $5.17 a$ & $\begin{array}{c}y=-0.6691^{* *} x+9.2137 \\
R^{2}=0.9227\end{array}$ \\
\hline $\mathrm{MgCl}_{2}$ & $8.34 a$ & $7.35 a$ & $6.47 a$ & $5.83 a$ & $4.75 b$ & $4.29 b$ & $\begin{array}{c}y=-0.8197^{* *} x+9.6145 \\
R^{2}=0.9917\end{array}$ \\
\hline $\mathrm{KCl}$ & $9.03 a$ & $8.17 a$ & $6.86 a$ & $6.17 a$ & $5.50 a$ & $4.86 a b$ & $\begin{array}{c}y=-0.8443^{* *} x+10.311 \\
R^{2}=0.9825\end{array}$ \\
\hline
\end{tabular}

${ }^{1}$ Different letters in the column indicate significant differences between the cationic natures at the 0.05 probability level by the test of means (Tukey). $\mathrm{EC}_{\mathrm{ns}}$ : electrical conductivity of the nutrient solution; CN: cationic nature; CV : coefficient of variation.

Reductions in TFM and SFM in leafy vegetables under salt stress in hydroponic systems have also been found by other authors; for instance, similar results were reported in coriander (Rebouças et al., 2013) and basil (Bione et al., 2014), confirming that salinity causes disorders in plant metabolism, leading to the restriction of growth and the loss in yield (Silveira et al., 2016). However, despite the decrease in production with increasing salts, satisfactory fresh mass values reaching $50 \mathrm{~g}$ of parsley were observed.

For these two variables, it is interesting to note that under replacement with brackish water, under high $\mathrm{EC}_{\mathrm{ns}}$, the osmotic effect can be more deleterious than the ionic effect with respect to the production of crops.

For the RFM, a significant response to the interactions between the treatments $(p<0.05)$ was only observed under replacement with brackish water, from $5.7 \mathrm{dS} \mathrm{m}^{-1}$, which was different from the other plant parts (Table 2). It is worth pointing out the difference $(\mathrm{p}<0.01)$ of $17 \%$ in the RFM of the plants exposed to $\mathrm{CaCl}_{2}$ and $\mathrm{MgCl}_{2}$, which may be related to the lower absorption of $\mathrm{Mg}$ because it has a very high hydration energy, which causes its attraction to binding sites in the plasma membrane to be particularly low, leading to low rates of absorption of this nutrient by plants (Marschner, 1986).

The $\mathrm{EC}_{\mathrm{ns}}$ caused significant differences $(\mathrm{p}<0.05)$ in the total dry matter (TDM), the shoot dry matter (SDM) and the root dry matter (RDM) and in the percentages of total dry matter (\%TDM), the shoot dry matter (\%SDM) and the root dry matter (\%RDM) under replacement with municipal-supply water. The interaction between the factors had a significant influence $(p<0.05)$ on the TDM, $\mathrm{SDM}, \mathrm{RDM}$ and $\% \mathrm{RDM}$. In addition, the \%SDM was also affected $(\mathrm{p}<0.05)$ by the cationic nature (Table 3 ).

There was a linear reduction in the TDM with the increase in $\mathrm{EC}_{\mathrm{ns}}$ under replacement with municipal-supply water. However, the difference between the effect of the salts was only observed from $4.7 \mathrm{dS} \mathrm{m}^{-1}$, with more expressive results related to $\mathrm{NaCl}$ and $\mathrm{KCl}$ than to $\mathrm{CaCl}_{2}$ and $\mathrm{MgCl}_{2}$, whose mean difference reached $29.45 \%$ at an $\mathrm{EC}_{\mathrm{ns}}$ of $6.7 \mathrm{dS} \mathrm{m}^{-1}$ (Table 3 ).

A linear reduction was also found in the SDM as the $\mathrm{EC}_{\mathrm{ns}}$ increased under replacement with municipal-supply water. Analogously, different responses to the cationic nature were observed when municipal-supply water was used in the replacement, also from $4.7 \mathrm{dS} \mathrm{m}^{-1}$, especially under $\mathrm{NaCl}$ and $\mathrm{KCl}$, compared to $\mathrm{CaCl}_{2}$ and $\mathrm{MgCl}_{2}$ (Table 3). 
Table 3: The total dry matter (TDM), shoot dry matter (SDM) and root dry matter (RDM) and the percentages of total dry matter (\%TDM), the shoot dry matter (\%SDM) and the root dry matter (\%RDM) results of parsley plants, cv. 'Graúda Portuguesa', exposed to isosmotic brackish nutrient solutions prepared in waters with different cationic natures and responses with municipal-supply water.

\begin{tabular}{|c|c|c|c|c|c|c|c|}
\hline \multicolumn{8}{|c|}{ EC of the nutrient solution $\left(\mathrm{dS} \mathrm{m}^{-1}\right)$} \\
\hline & 1.7 & 2.7 & 3.7 & 4.7 & 5.7 & 6.7 & \\
\hline \multicolumn{8}{|c|}{${ }^{1}$ TDM (g) - Municipal-supply (EC $\left.{ }_{n s}: p<0.05, C N: p<0.05, E C_{n s} v s C N: p<0.05, C V=5.66 \%\right)$} \\
\hline $\mathrm{NaCl}$ & $11.78 \mathrm{a}$ & $9.00 a$ & $7.92 a$ & $7.34 a$ & $6.64 a$ & $5.16 a$ & $\begin{array}{c}y=-1.1646^{* *} x+12.865 \\
R^{2}=0.9256\end{array}$ \\
\hline $\mathrm{CaCl}_{2}$ & $10.22 \mathrm{a}$ & $8.71 a$ & $7.63 a$ & $6.90 \mathrm{ab}$ & $4.42 b$ & $3.64 b$ & $\begin{array}{c}y=-1.3286^{* *} x+12.5 \\
R^{2}=0.9773\end{array}$ \\
\hline $\mathrm{MgCl}_{2}$ & $10.43 a$ & $8.87 a$ & $7.83 a$ & $5.50 \mathrm{~b}$ & $4.56 b$ & $3.96 b$ & $\begin{array}{c}y=-1.3603^{* *} x+12.572 \\
R^{2}=0.9731\end{array}$ \\
\hline $\mathrm{KCl}$ & $10.69 a$ & $8.94 a$ & $7.81 a$ & 7.07a & $6.50 a$ & $5.08 a$ & $\begin{array}{c}y=-1.0317^{* *} x+12.015 \\
R^{2}=0.9707\end{array}$ \\
\hline \multicolumn{8}{|c|}{${ }^{1}$ SDM (g) - Municipal-supply (EC ${ }_{n:}$ : $\left.p<0.05, C N: p<0.05, E_{n s} v S C N: p<0.05, C V=5.69 \%\right)$} \\
\hline $\mathrm{NaCl}$ & $8.36 a$ & $7.53 a$ & $6.83 a$ & $6.45 a$ & $5.85 a$ & $4.47 a$ & $\begin{array}{c}y=-0.7106^{* \star} x+9.5661 \\
R^{2}=0.9672\end{array}$ \\
\hline $\mathrm{CaCl}_{2}$ & $8.14 a$ & $7.12 \mathrm{a}$ & $6.73 a$ & $6.25 a$ & $4.00 \mathrm{~b}$ & $3.35 b$ & $\begin{array}{c}y=-0.9654^{* *} x+9.9865 \\
R^{2}=0.9361\end{array}$ \\
\hline $\mathrm{MgCl}_{2}$ & $8.24 a$ & 7.66a & $6.86 a$ & $4.74 b$ & $4.00 \mathrm{~b}$ & $3.53 b$ & $\begin{array}{c}y=-1.0471 * * x+10.236 \\
R^{2}=0.9573\end{array}$ \\
\hline $\mathrm{KCl}$ & $8.56 a$ & $7.34 a$ & $6.82 \mathrm{a}$ & $6.34 a$ & $5.73 a$ & $4.42 \mathrm{a}$ & $\begin{array}{c}y=-0.7431^{* *} x+9.6562 \\
R^{2}=0.9675\end{array}$ \\
\hline \multicolumn{8}{|c|}{${ }^{1}$ RDM (g) - Municipal-supply (EC $\left.{ }_{n s}: p<0.05, C N: p<0.05, E C_{n s} v s C N: p<0.05, C V=5.98 \%\right)$} \\
\hline $\mathrm{NaCl}$ & $2.60 a$ & $1.77 a$ & $1.08 \mathrm{a}$ & $0.88 a$ & $0.79 a$ & $0.69 a$ & $\begin{array}{c}y=-0.3626^{* *} x+2.8245 \\
R^{2}=0.8311\end{array}$ \\
\hline $\mathrm{CaCl}_{2}$ & $2.07 a$ & $1.59 a b$ & $0.90 a$ & $0.65 a$ & $0.41 a$ & $0.29 b$ & $\begin{array}{c}y=-0.3626^{* *} x+2.5078 \\
R^{2}=0.9290\end{array}$ \\
\hline $\mathrm{MgCl}_{2}$ & $2.18 a$ & $1.20 b$ & $0.96 a$ & $0.76 a$ & $0.56 a$ & $0.43 b$ & $\begin{array}{c}y=-0.3106^{* *} x+2.3194 \\
R^{2}=0.8403\end{array}$ \\
\hline $\mathrm{KCl}$ & $2.13 a$ & $1.59 a b$ & $0.99 a$ & $0.82 \mathrm{a}$ & $0.77 a$ & $0.66 a$ & $\begin{array}{c}y=-0.2851 * * x+2.3576 \\
R^{2}=0.8508\end{array}$ \\
\hline $\begin{array}{l}\% \text { TDM }(\% \\
\left(E C_{n s}: p<0\right.\end{array}$ & $\begin{array}{l}\text { - Munici } \\
\text { 05, CN: } p\end{array}$ & $\begin{array}{l}\text { bal-supply } \\
>0.05, E C_{n}\end{array}$ & vsCN: $\mathrm{p}>$ & $.05, \mathrm{CV}=$ & $4.63 \%)$ & & $\begin{array}{c}y=0.5209 * * x+13.547 \\
R^{2}=0.816\end{array}$ \\
\hline $\begin{array}{l}\% S D M(\% \\
\left(E C_{n s}: p<0\right.\end{array}$ & $\begin{array}{l}\text { - Munici } \\
\text { 05, CN: } p\end{array}$ & $\begin{array}{l}\text { ol-supply } \\
0.05, E C_{n \leq}\end{array}$ & vsCN: $\mathrm{p}>$ & $0.05, \mathrm{CV}=$ & $8.06 \%)$ & & $y=0.9557 * * x+13.941$ \\
\hline & & $\begin{array}{c}\mathrm{NaCl} \\
17.97 \mathrm{ab}\end{array}$ & $\begin{array}{c}\mathrm{CaCl}_{2} \\
18.64 \mathrm{a}\end{array}$ & $\begin{array}{l}\mathrm{MgCl}_{2} \\
16.35 \mathrm{~b}\end{array}$ & $\begin{array}{c}\mathrm{KCl} \\
18.87 \mathrm{a}\end{array}$ & & $\mathrm{R}^{2}=0.9724$ \\
\hline \multicolumn{8}{|c|}{ 1\%RDM (\%) - Municipal-supply (EC $\left.{ }_{n s}: p<0.05, C N: p<0.05, E_{n s} v s C N: p<0.05, C V=9.74 \%\right)$} \\
\hline $\mathrm{NaCl}$ & $13.88 a$ & $9.91 a$ & $9.03 a$ & $9.06 a$ & $9.20 a$ & $10.15 a b$ & $\begin{array}{c}y=0.5121 * * x^{2}-4.8949 x+20.235 \\
R^{2}=0.9217\end{array}$ \\
\hline $\mathrm{CaCl}_{2}$ & $11.43 a$ & $11.06 a$ & $8.07 a$ & $8.54 a$ & $7.30 \mathrm{~b}$ & $8.47 \mathrm{~b}$ & $\begin{array}{c}y=0.2625 * * x^{2}-2.9367 x+16.083 \\
R^{2}=0.8369\end{array}$ \\
\hline $\mathrm{MgCl}_{2}$ & $13.17 a$ & $9.62 a$ & $9.51 a$ & $10.29 a$ & $10.71 a$ & $12.02 \mathrm{a}$ & $\begin{array}{c}y=0.4718^{* *} x^{2}-4.0116 x+18.037 \\
R^{2}=0.8041\end{array}$ \\
\hline $\mathrm{KCl}$ & $12.42 \mathrm{a}$ & $11.63 a$ & $8.74 a$ & $8.64 a$ & $9.66 a$ & $10.94 a$ & $\begin{array}{c}y=0.4641 * * x^{2}-4.2816 x+18.781 \\
R^{2}=0.8652\end{array}$ \\
\hline
\end{tabular}

${ }^{1}$ Different letters in the column indicate significant differences between the cationic natures at the 0.05 probability level by the test of means (Tukey). $\mathrm{EC}_{\mathrm{ns}}$ : electrical conductivity of the nutrient solution; CN: cationic nature; CV : coefficient of variation. 
Under replacement with municipal-supply water, there were losses up to $73.46 \%, 85.99 \%, 80.27 \%$ and $69.01 \%$ in the RDM of the plants exposed to the nutrient solutions based on $\mathrm{NaCl}, \mathrm{CaCl}_{2}, \mathrm{MgCl}_{2}$ and $\mathrm{KCl}$, respectively, within the salinity range from $1.7 \mathrm{dS} \mathrm{m}^{-1}$ to $6.7 \mathrm{dS} \mathrm{m}^{-1}$. Regarding the cationic natures of the water, higher results were found for $\mathrm{NaCl}$ and $\mathrm{KCl}$, and lower results were observed for $\mathrm{MgCl}_{2}$ and $\mathrm{CaCl}_{2}$ at levels of 2.7 and $6.7 \mathrm{dS} \mathrm{m}^{-1}$, respectively (Table 3 ).

The similar behaviors for these two salts $(\mathrm{NaCl}$ and $\mathrm{KCl}$ ) may be related to the fact that $\mathrm{K}$ and $\mathrm{Na}$ have a common absorption mechanism that is regulated by their concentrations in the nutrient solution. Thus, high $\mathrm{K}$ levels can modify $\mathrm{Na}$ uptake and transport and limit the toxic damage of this nutrient (Schachtman; Schroeder, 1994).

For the \% TDM and \% SDM, under replacement with municipal-supply water, there was a linear increase with the increase in nutrient solution electrical conductivity, with gains of $14.67 \%$ for the $\%$ TDM and $22.66 \%$ for the $\%$ SDM. Nonetheless, only the \%SDM demonstrated a significant influence $(p<0.05)$ on the cationic nature, with higher gains in the solutions based on $\mathrm{KCl}$ (Table 3).
The \%RDM showed minimum values of $8.53 \%$, $7.86 \%, 9.50 \%$ and $8.90 \%$ in the solutions based on $\mathrm{NaCl}$, $\mathrm{CaCl}_{2}, \mathrm{MgCl}_{2}$ and $\mathrm{KCl}$, respectively. In relation to the cationic nature, from $5.7 \mathrm{dS} \mathrm{m}^{-1}$, less expressive results were observed in the solutions based on $\mathrm{CaCl}_{2}$.

The $\mathrm{EC}_{\mathrm{ns}}$ caused a significant difference $(\mathrm{p}<0.05)$ in the total dry matter (TDM), the shoot dry matter (SDM) and the root dry matter (RDM) and in the percentages of the total dry matter (\%TDM), the shoot dry matter $(\% \mathrm{SDM})$ and the root dry matter (\%RDM) under replacement with brackish water. The cationic nature had a significant influence $(\mathrm{p}<0.05)$ on the TDM, SDM and \%RDM (Table 4).

There was a linear reduction in the TDM with the increase in $\mathrm{EC}_{\mathrm{ns}}$ under replacement with brackish water regardless of the type of salt, which individually demonstrated more expressive values in the solutions based on $\mathrm{NaCl}$. The use of brackish water in the replacement resulted in a relative loss estimated at $42.23 \%$ within the studied interval of the $\mathrm{EC}_{\mathrm{ns}}$.

A linear reduction was also found in the SDM as the $\mathrm{EC}_{\mathrm{ns}}$ increased and under replacement with brackish

Table 4: The total dry matter (TDM), shoot dry matter (SDM) and root dry matter (RDM) and the percentages of total dry matter (\%TDM), the shoot dry matter (\%SDM) and the root dry matter (\%RDM) results of parsley plants, cv. 'Graúda Portuguesa', exposed to isosmotic brackish nutrient solutions prepared in waters with different cationic natures and responses with brackish water.

\begin{tabular}{|c|c|c|c|c|}
\hline \multicolumn{4}{|c|}{ EC of the nutrient solution $\left({\left.\mathrm{dS} \mathrm{m}^{-1}\right)}\right.$} & \multirow{4}{*}{$\begin{array}{l}y=-0.8089 * * x+10.699 \\
R^{2}=0.9969\end{array}$} \\
\hline \multicolumn{4}{|c|}{$\begin{array}{l}\text { TDM (g) - Brackish } \\
\left(E C_{n s}: p<0.05, C N: p<0.05, E C_{n s} v s C N: p>0.05, C V=7.82 \%\right)\end{array}$} & \\
\hline $\mathrm{NaCl}$ & $\mathrm{CaCl}_{2}$ & $\mathrm{MgCl}_{2}$ & $\mathrm{KCl}$ & \\
\hline $7.54 a$ & $7.27 a b$ & $7.31 \mathrm{ab}$ & $7.10 b$ & \\
\hline \multicolumn{4}{|c|}{$\begin{array}{l}\operatorname{SDM}(g)-\text { Brackish } \\
\left(E_{n s}: p<0.05, N C: p<0.05, E C_{n s} v s C N: p>0.05, C V=8.66 \%\right)\end{array}$} & \multirow{3}{*}{$\begin{array}{c}y=-0.74^{* *} x+9.648 \\
R^{2}=0.9972\end{array}$} \\
\hline $\mathrm{NaCl}$ & $\mathrm{CaCl}_{2}$ & $\mathrm{MgCl}_{2}$ & $\mathrm{KCl}$ & \\
\hline $6.78 a$ & $6.49 a b$ & $6.54 a b$ & $6.35 b$ & \\
\hline \multicolumn{4}{|c|}{$\begin{array}{l}\text { RDM (g) - Brackish } \\
\left(E C_{n s}: p<0.05, C N: p>0.05, E_{n s} v s C N: p>0.05, C V=6.64 \%\right)\end{array}$} & $\begin{array}{c}y=-0.0689 * * x+1.0475 \\
R^{2}=0.9891\end{array}$ \\
\hline \multicolumn{4}{|c|}{$\begin{array}{l}\text { \%TDM (\%) - Brackish } \\
\left(E C_{n s}: p<0.05, C N: p>0.05, E C_{n s} v s C N: p>0.05, C V=9.43 \%\right)\end{array}$} & $\begin{array}{c}y=0.4586^{\star *} x+17.766 \\
R^{2}=0.8931\end{array}$ \\
\hline \multicolumn{4}{|c|}{$\begin{array}{l}\text { \%SDM (\%) - Brackish } \\
\left(\mathrm{EC}_{n s}: p<0.05, C N: p>0.05, E_{n s} v s C N: p>0.05, C V=10.87 \%\right)\end{array}$} & $\begin{array}{c}y=0.5326^{* *} x+19.11 \\
R^{2}=0.8825\end{array}$ \\
\hline \multicolumn{4}{|c|}{ \%RDM (\%) - Brackish ( $\left.E C_{n s}: p<0.05, C N: p<0.05, E C_{n s} v s C N: p>0.05, C V=9.53 \%\right)$} & \multirow{3}{*}{$\begin{array}{c}y=0.332^{* *} x+10.569 \\
R^{2}=0.9765\end{array}$} \\
\hline $\mathrm{NaCl}$ & $\mathrm{CaCl}_{2}$ & $\mathrm{MgCl}_{2}$ & $\mathrm{KCl}$ & \\
\hline $11.76 b c$ & $12.32 \mathrm{ab}$ & $12.61 \mathrm{a}$ & $11.15 \mathrm{c}$ & \\
\hline
\end{tabular}

${ }^{1}$ Different letters in the column indicate significant differences between the cationic natures at the 0.05 probability level by the test of means (Tukey). $\mathrm{EC}_{\mathrm{n}}$ : electrical conductivity of the nutrient solution; CN: cationic nature; CV : coefficient of variation. 
water, and among the cationic natures studied, the plants cultivated with $\mathrm{NaCl}$ were shown to be less sensitive to the salinity increase of the nutrient solution.

This may be related to the fact that the root system has proteins that are present in the plasmalemma of epidermal cells and can exclude $\mathrm{Na}^{+}$from the cytosol to the outside; also, when this is carried out, it may lead to the deposition of this ion in the xylem, and consequently, transpiration flow may favor the transfer of $\mathrm{Na}^{+}$to the shoots. Therefore, this transport system can be directly involved with mechanisms that regulate the transport and distribution of this ion in the plant (Silveira et al., 2016).

Under replacement with brackish water, there was an estimated reduction of $6.02 \%$ in the RDM per $\mathrm{dS} \mathrm{m}^{-1}$ (Table 4). However, for the \%TDM, there was a linear increase with the increment in nutrient solution electrical conductivity, with gains of $10.74 \%$; in the same way as the $\% \mathrm{SDM}$, there were also linear increments as the salinity increased under replacement with brackish water (11.51\%) (Table 4).

Under replacement with brackish water, the plants grown in the solutions containing $\mathrm{CaCl}_{2}$ and $\mathrm{MgCl}_{2}$ showed a higher \% RDM, and an increment up to $12.37 \%$ was estimated when the \%RDM was compared between the plants, at 1.7 and $6.7 \mathrm{dS} \mathrm{m}^{-1}$ (Table 4).

In both experiments, there was a tendency of growth in the accumulation of dry mass with the increase in salinity; analogously, an increase in dry matter content in plants under salt stress has also been observed in pepper (Piñero et al., 2014) and lettuce (Pérez-López et al., 2013), which may be attributed to the maintenance of high turgor in the tissues due to efficient stomatal closure (Pirasteh-Anosheh et al., 2016) and consequently greater $\mathrm{CO}_{2}$ fixation.

\section{CONCLUSIONS}

The percentages of shoot and root dry matter increased with increasing electrical conductivity. Greater reductions were observed in the fresh and dry mass when the volume consumed was replaced with brackish water. The use of municipal-supply water mitigated the effects of the salts on the production variables and the dry matter content of the parsley plants. Although reductions were observed with the increment of $\mathrm{EC}_{\mathrm{ns}}$ in both strategies of replacement, the results of parsley production were satisfactory.

\section{ACKNOWLEDGMENTS}

The authors thank the Coordination for the Improvement of Higher Education Personnel (CAPES) and the National Council for Scientific and Technological Development $(\mathrm{CNPq})$ for the project financing.

\section{REFERENCES}

ABRAHÃO, C.; BÔAS, R. L. V.; BULL, L. T. Relação K:Ca:Mg na solução nutritiva para a produção de minitomate cultivado em substrato. Irriga, 19(2):214-224, 2014.

BIONE, M. A. A. et al. Crescimento e produção de manjericão em sistema hidropônico NFT sob salinidade. Revista Brasileira de Engenharia Agrícola e Ambiental, 18(12):1228-1234, 2014.

CAMPOS JÚNIOR, J. E. et al. Rocket production in a low cost hydroponic system using brackish water. Revista Caatinga, 31(4):1008-1016, 2018.

FERREIRA, D. F. Sisvar: A computer statistical analysis system. Ciência e Agrotecnologia, 35(6):1039-1042, 2011.

FREITAS, L. D. A. et al. Crescimento e produção do meloeiro cultivado sob diferentes níveis de salinidade e nitrogênio. Revista Brasileira de Engenharia Agrícola e Ambiental, 18(Suplemento):20-26, 2014.

FURLANI, P. R. et al. Cultivo hidropônico de plantas. Campinas: Instituto Agronômico, 1999. 52p. (Boletim Técnico IAC, 180), 1999.

GUEDES, R. A. A. et al. Estratégias de irrigação com água salina no tomateiro cereja em ambiente protegido. Revista Brasileira de Engenharia Agrícola e Ambiental, 19(10):913-919, 2015.

HOLANDA, J. S. et al. Qualidade da água para irrigação. In: GHEYI, H. R.; DIAS, N. S.; LACERDA, C. F. Manejo da Salinidade na Agricultura: Estudos Básicos e Aplicados. (p.35-47). Fortaleza: INCTSal, 2016. v.2, p.35-47.

LAKO, J. et al. Phytochemical flavonols, carotenoids and the antioxidant properties of a wide selection of Fijian fruit, vegetables and other readily available foods. Food Chemistry, 101(4):1727-1741, 2007.

MAODAA, S. N. et al. Effect of parsley (Petroselinum crispum, Apiaceae) juice against cadmium neurotoxicity in albino mice (Mus musculus). Behavioral and Brain Functions, 12(6):1-16, 2016

MARSCHNER, H. Mineral nutrition of higer plants. London: Academic Press, 1986. 674p.

MONTENEGRO, S. G. L. et al. Experimentação e modelagem do avanço de sais no perfil do solo em área cultivada com repolho sob alternativas de manejo de irrigação, no semiárido de Pernambuco. Revista Brasileira de Ciências Agrárias, 8(1):148-155, 2013. 
MUNNS, R.; GILLIHAM, M. Salinity tolerance of crops - What is the cost? New Phytologist, 208(3):668-673, 2015.

NIRUMAND, M. C. et. al. Dietary plants for the prevention and management of kidney stones: Preclinical and clinical evidence and molecular mechanisms. International Journal of Molecular Sciences, 19(765):1-24, 2018.

PÉREZ-LÓPEZ, U. et al. Lettuce production and antioxidant capacity are differentially modified by salt stress and light intensity under ambient and elevated $\mathrm{CO}_{2}$. Journal of Plant Physiology, 170(17):1517-1525, 2013.

PIÑERO, M. C. et al. Regulation of hormonal responses of sweet pepper as affected by salinity and elevated $\mathrm{CO}_{2}$ concentration. Physiologia Plantarum, 151(4):375-389, 2014.

PIRASTEH-ANOSHEH, H. et al. Stomatal responses to drought stress. In: Parvaiz Ahmad. Water Stress and Crop Plants: A Sustainable Approach. Wiley: Chichester, v.1, p.22-44, 2016.

REBOUÇAS, J. R. L. et al. Cultivo hidropônico de coentro com uso de rejeito salino. Irriga, 18(4):624-634, 2013.

REIS, R. C. et al. Compostos bioativos e atividade antioxidante de variedades melhoradas de mamão. Ciência Rural, 45(11):2076-2081, 2015.

SANTOS JÚNIOR, J. A. et al. Crescimento do girassol em sistema semi-hidropônico sob estresse salino e densidades de plantio. Irriga, 20(2):233-247, 2015.

SANTOS JÚNIOR, J. A. et al. Produção e pós-colheita de flores de girassóis sob estresse salino em hidroponia de baixo custo. Engenharia Agrícola, 36(3):420-432, 2016.
SANTOS, N. A. et al. Concentração de nutrientes em tomate cereja sob manejos deaplicação da solução nutritiva com água salobra. Revista Ciência Agronômica, 48(4):576-585, 2017.

SCHACHTMAN, D. P.; SCHROEDER, J. I. Structure and transport mechanism of a high-affinity potassium uptake transporter from higher plants. Nature, 370(6491):655-658, 1994.

SILVA, J. S. et al. Production of lettuce with brackish water in NFT hydroponic system. Semina: Ciências Agrárias, 39(3):947-962, 2018.

SILVA, M. G. et al. Produção de coentro em hidroponia NFT com o uso de águas salobras para reposição do consumo evapotranspirado. Revista Brasileira de Agricultura Irrigada, 9(4):246-258, 2015.

SILVEIRA, J. A. G. et al. Mecanismos biomoleculares envolvidos com a resistência ao estresse salino em plantas. In: GHEYI, H. R.; DIAS, N. S.; LACERDA, C. F. Manejo da salinidade na agricultura: Estudo básico e aplicados. Fortaleza: INCTSal, 2016. v.2, p.181-196.

SNOUSSI, M. et al. Chemical composition and antibiofilm activity of Petroselinum crispum and Ocimum basilicum essential oils against Vibrio spp. strains. Microbial Pathogenesis, 90:13-21, 2016.

SOUZA NETA, M.L. et al. Efeitos da salinidade sobre o desenvolvimento de rúcula cultivada em diferentes substratos hidropônicos. Revista Agro@mbiente On-line, 7(2):154-161, 2013.

TORRES, E. C. M. et al. Biometria de mudas de cajueiro anão irrigadas com águas salinas e uso de atenuadores do estresse salino. Nativa, 2(2):71-78, 2014. 